\title{
Family Planning as a Christian Global Health Agenda
}

\author{
W. Henry Mosley ${ }^{a}$ \\ ${ }^{a}$ MD, MPH, Professor Emeritus, Department of Population, Family and Reproductive Health, \\ Johns Hopkins Bloomberg School of Public Health
}

The Christian Journal for Global Health is coming at an opportune time in terms of looking at issues of global health and development. In the next year, we will be coming to the end of the period of the Millennium Development Goals (MDGs) for 2015, and will be looking forward to the challenges of the post-2015 development agenda. Although this is a secular agenda, it is consistent with the Christian values of global poverty alleviation and the improvement of the health and welfare of the disadvantaged peoples around the world. Christian organizations and individuals will be active participants in contributing to these new goals as they have been with the MDGs.

In this context, I would like to highlight one of the most cost-effective public health interventions available that should be an integral part of every Christian health program. This is family planning - as defined by Christian Connections for International Health (CCIH - a network of over 170 Christian organizations) to mean “...enabling couples to determine the number and timing of their pregnancies, including voluntary use of methods for preventing pregnancy, not including abortion, harmonious with their values and religious beliefs."

Why should Christians in international health give special attention to family planning? First of course, it has well documented direct health benefits in saving the lives and improving the health of mothers and children. Second, it promotes family, community and national wellbeing, both socially and economically. Third, of special interest to Christians, by preventing unintended pregnancies, family planning prevents abortions. $^{2}$
Let's look at the data, first globally and then in two countries - Bangladesh and Nigeria where I have worked over the years. Globally, there are an estimated 80 million unintended pregnancies annually, and 42 million of these end in abortion. At the same time it is estimated that there are 222 million women with an unmet need for contraception. If this unmet need could be met, an estimated 54 million unintended pregnancies and 26 million abortions could be prevented every year. ${ }^{3}$

Bangladesh and Nigeria provide informative case studies as it relates to family planning and the achievement of the MDGs. Both had comparably large populations in 1970- Nigeria with 57 million and Bangladesh with 67 million - and each had fertility rates of over 6 births per woman. With a longer period of independence and oil production, Nigeria has had considerable social and economic advantages over Bangladesh, a new country gaining independence from Pakistan in 1971.

Bangladesh initiated an effective family planning program in the 1970 s with fertility rates declining over the ensuing years to the current level of 2.3 births per woman. By contrast, family planning has not taken hold in Nigeria so that the current fertility rate is still 5.5 births per woman. 4,5 As a consequence of these divergent trends, between 1990 and 2013 the number of births annually in Bangladesh declined by $10 \%$ from 4 million to 3.6 million, while in Nigeria the number of annual births rose by $58 \%$ from 4.4 million to 6.8 million in the same period.

These dramatically different fertility trends have had significant consequences in terms of achieving the MDGs. To cite a few, since 2000, female primary school attendance rates in Bangla-

Nov 2014. Christian Journal for Global Health, 1(2):4-6. 
desh have risen from $33 \%$ to $82 \%$, while in Nigeria these have virtually stagnated, only rising from $54 \%$ to $62 \%$. ${ }^{6,7}$ Childhood immunization rates have now reached $86 \%$ in Bangladesh, but only $25 \%$ in Nigeria, under-5 mortality is $64 / 1000$ in Bangladesh compared to $144 / 1000$ in Nigeria and the maternal mortality ratio is $170 / 100,000$ live births in Bangladesh compared to 560/100,000 in Nigeria. ${ }^{4,5,8}$

Induced abortions are hard to measure but a well-documented study in Bangladesh showed that abortion rates dropped by $58 \%$ and $68 \%$ in the 1980s and 1990s respectively in an area where an intensive family planning program was implemented compared to an area without these services. ${ }^{9} \quad$ By contrast, in Nigeria a 2006 study gave a conservative estimate of 760,000 induced abortions, the majority among women not using contraception. Put another way, among sexually active women ages 15-49 years, 1 in 7 attempted an abortion, and 1 in 10 were completed. ${ }^{10}$ It is estimated that half of all maternal deaths in the major city of Lagos are due to abortions. ${ }^{11}$

Fortunately, the family planning picture in Nigeria is not representative of all of Sub-Saharan Africa. This is in no small measure because, beyond strong government support in many African countries, there are networks of Christian health institutions that have made family planning integral to their operations. These national Christian Health Associations in 21 countries have come together to form the Africa Christian Health Associations' Platform (ACHAP). ACHAP, among other activities, has advocated for family planning support to the UNFPA, at international public health meetings, and with $\mathrm{CCIH}$ to the US Congress. ${ }^{12}$

Christian health professionals concerned about meeting the holistic health needs of their communities should have no hesitation in integrating family planning into their programs. There is no other single public health intervention that can meet not only their physical needs, but also promote their mental, social and spiritual wellbeing and the welfare of their families, communities and nations.

\section{References}

1. CCIH. Think you know where Christians stand on family planning? Think again. November, 2013. [cited 2014 Oct 10]. Available from: http://www.ccih.org/Hill-Fact-Sheet-FP.pdf

2. CCIH. Family Planning Reduces Abortions and Faith Based Groups Can Help. January, 2014. [cited 2014 Oct 10]. Available from: http://www.ccih.org/FP-Reduces-Abortions.pdf

3. Singh S, Darroch JE. Adding it up: Costs and benefits of contraceptive services-estimates for 2012. Guttmacher Institute and United Nations Population Fund (UNFPA), 2012. [cited 2014 Oct 10]. Available from: http://www.guttmacher.org/pubs/AIU-2012estimates.pdf

4. Bangladesh Demographic and Health Survey, 2011. [cited 2014 Oct 10]. Available from: http://dhsprogram.com/pubs/pdf/FR265/FR265.p df

5. Nigeria Demographic and Health Survey, 2013. [cited 2014 Oct 10]. Available from: http://dhsprogram.com/pubs/pdf/FR293/FR293.p df

6. Primary school gross and net attendance rates, Bangladesh. [cited 2014 Oct 10]. Available from: http://www.epdc.org/sites/default/files/document s/Bangladesh coreusaid.pdf

7. Primary school gross and net attendance rates, Nigeria. [cited 2014 Oct 10]. Available from: http://www.epdc.org/sites/default/files/document s/Nigeria coreusaid.pdf

8. Trends in maternal mortality: 1990 - 2013. WHO, UNICEF, UNFPA and the World Bank estimates. WHO, 2012. [cited 2014 Oct 10]. Available from: http://apps.who.int/iris/bitstream/10665/112682 L2/9789241507226 eng.pdf

9. Rahman M, DaVanzo J, Razzaque A. Do better family planning services reduce abortion in Bangladesh? Lancet 2001; 358: 1051-56.

http://dx.doi.org/10.1016/S0140-6736(01)06182$\underline{7}$

10. Bankole A, et al. Unwanted pregnancy and induced abortion in Nigeria: Causes and consequences. Guttmacher Institute, 2006. [cited 2014 Oct 10].

Nov 2014. Christian Journal for Global Health, 1(2):2-4. 
Available from:

http://www.guttmacher.org/pubs/2006/08/08/Ni geria-UP-IA.pdf

11. Gaestel A. How do you get an abortion in Lagos? The Pulitzer Center on Crisis Reporting, September 25, 2013. [cited 2014 Oct 12]. Available from: http://pulitzercenter.org/reporting/africa-nigeria- abortion-methods-maternal-health-fertilitypregnancy

12. Mwenda S. ACHAP-CCIH Partnership Takes Advocacy to US Congress. [cited 2014 Oct 5]. Available from:

http://www.africachap.org/x5/index.php?option $=\mathrm{c}$ om content\&task=view\&id=35\&Itemid=62

Competing Interests: None declared. Dr. Mosley is a member of the International Advisory Board of CJGH.

Correspondence: W. Henry Mosley, Johns Hopkins Bloomberg School of Public Health, Baltimore, MD, USA. hmosley@jhsph.edu

Cite this article as: Mosley, W Henry. Family Planning as a Christian global health agenda. Christian Journal for Global Health (Nov 2014), 1(2):2-4. http://dx.doi.org/10.15566/cigh.v1i2.47

(c) Mosley WH. This is an open-access article distributed under the terms of the Creative Commons Attribution License, which permits unrestricted use, distribution, and reproduction in any medium, provided the original author and source are properly cited. To view a copy of the license, visit http://creativecommons.org/licenses/by/3.0/

www.cjgh.org

Nov 2014. Christian Journal for Global Health, 1(2):2-4. 